\title{
AKTIVITAS DAN KARAKTERISASI ENZIM PROTEASE ISOLAT Bacillus sp. (UJ132) SECARA KUALITATIF DAN KUANTITATIF
}

\author{
Sumardi", Salman Farisi, Chiristina Nugroho Ekowati, dan Milsa Solva Diana \\ Jurusan Biologi, Fakultas Matematika dan IImu Pengetahuan Alam, Universitas Lampung \\ Jl. Soemantri Brojonegoro No. 1, Gedong Meneng, Bandar Lampung 35145 \\ (Naskah diterima: 5 April 2019; Revisi final: 23 Agustus 2019; Disetujui publikasi: 23 Agustus 2019)
}

\begin{abstract}
ABSTRAK
Bakteri penghasil enzim protease memiliki kemampuan untuk melakukan bioremediasi limbah protein. Penelitian ini dilakukan untuk mengetahui aktivitas dan karakterisasi enzim protease dari isolat Bacillus sp. (UJ132) yang diisolasi dari udang pasir (M etapenaeus affinis) di kawasan hutan mangrove Desa Margasari, Lampung Timur. Uji aktivitas enzim dilakukan secara kualitatif dan kuantitatif. Karakterisasi enzim meliputi penentuan suhu dan pH optimum, pengaruh ion logam, serta penentuan Km dan Vmaks. Dari hasil percobaan diketahui bahwa enzim protease dihasilkan pada waktu produksi optimum $18 \mathrm{jam}$ dengan aktivitas protease sebesar $0,09 \mathrm{U} / \mathrm{mL}$. Suhu optimum enzim ini yaitu pada suhu $50^{\circ} \mathrm{C}$ yang menghasilkan aktivitas sebesar $0,08 \mathrm{U} / \mathrm{mL}$. Enzim protease ini mempunyai kondisi optimum pada pH 5 dengan nilai aktivitas $0,09 \mathrm{U} / \mathrm{mL}$. Semua ion logam $\left(\mathrm{Ca}_{2}+, \mathrm{Mn}_{2}+, \mathrm{Cu}_{2}+, \mathrm{Mg}_{2}+\right)$ berfungsi sebagai inhibitor kecuali ion $\mathrm{Fe}_{3}{ }^{+}$yang berfungsi sebagai aktivator pada konsentrasi $1 \mathrm{mM}$ dan $5 \mathrm{mM}$. EDTA dengan konsentrasi $1 \mathrm{mM}$ dan $5 \mathrm{mM}$ berfungsi sebagai inhibitor pada enzim protease isolat UJ132. Nilai Vmaks enzim protease $0,33 \mathrm{U} / \mathrm{mL}$ sedangkan $\mathrm{Km}$ senilai $4,59 \mathrm{mg} / \mathrm{mL}$ substrat, enzim ini mempunyai afinitas yang tinggi terhadap substrat.
\end{abstract}

\section{KATA KUNCl: Bacillus sp.; bakteri proteolitik; hutan mangrove; probiotik; protease}

ABSTRACT: The activity and characterization of protease enzyme of Bacillus $\mathbf{s p .}$ UJ132, a probiotic candidate for shrimp farming. By: Sumardi, Salman Farisi, Chiristina Nugroho Ekowati, and Milsa Solva Diana

Shrimp farming produces protein wastes which mainly come from the remnants of given feed and excreta (feces) of shrimp. Bacteria known to possess protease enzymes have the ability to solve this protein waste problem in the shrimp farming industry. This study was conducted to determine the production and characterization of protease enzyme from Bacillus sp. (UJ132) isolated from the mangrove forest area of Margasari Village of Lampung Timur. The enzyme activity test was done qualitatively and quantitatively. The objectives of this study were to determine the optimum production of the enzymes and observe their characteristics, including determining the temperature and optimum pH, the effect of several metal ions, as well as Km and Vmax. The experimental results revealed that the protease enzyme had an optimum time of 18 hours of protease activity as much as $0.09 \mathrm{U} / \mathrm{mL}$. The optimum temperature of this enzyme was $50^{\circ} \mathrm{C}$ which produced an activity of $0.08 \mathrm{U} / \mathrm{mL}$. This protease enzyme has an optimum working condition at pH 5 with an activity value of $0.09 \mathrm{U} / \mathrm{mL}$. All metal ions ( $\mathrm{Ca} 2+, \mathrm{Mn} 2+, \mathrm{Cu} 2+, \mathrm{Mg} 2+$ ) acted as inhibitors except $\mathrm{Fe} 3+$ ions which acted as activators at concentrations of $1 \mathrm{mM}$ and $5 \mathrm{mM}$. EDTA with a concentration of $1 \mathrm{mM}$ and $5 \mathrm{mM}$ served as an inhibitor of $\mathrm{UJ} 132$ isolate protease enzyme. The value of $\mathrm{Vmax}$ of the protease enzyme was 0.33 $\mathrm{U} / \mathrm{mL}$ while $\mathrm{Km}$ was $4.59 \mathrm{mg} / \mathrm{mL}$ suggesting that this enzyme has a high affinity with the substrate.

KEYWORDS: Bacillus sp.; proteolytic bacteria; mangrove forest; probiotics; protease

\section{PENDAHULUAN}

Penggunaan mikroba probiotik di sektor budidaya udang yang telah menjadi kebiasaan saat ini. Penggunaan probiotik untuk pencegahan penyakit

\footnotetext{
\# Korespondensi: Fakultas Matematika dan IImu Pengetahuan Alam, Universitas Lampung. Jl. Soemantri Brojonegoro No. 1, Gedong Meneng, Bandar Lampung 35145, Indonesia.

Tel. + 62721704625

E-mail: sumardi.bio@yahoo.co.id
}

mempunyai keuntungan dibandingkan cara-cara pengendalian yang lainnya, karena: (1) menekan pertumbuhan bakteri pathogen vibrio; (2) mampu memperbaiki kualitas air (Moriarty, 1998); (3) bioremediasi kualitas air (Muliani et al., 2004); dan (4) efisiensi pada pakan (Murdianto, 2015).

Pakan udang dan ikan mengandung protein sebanyak 55,51\%67,68\% (Hany, 2011). Untuk 
meningkatkan penggunaan pakan yang efisien tersebut maka diperlukan beberapa mikroba probiotik yang dapat menghasilkan enzim protease. Beberapa mikroba diketahui sebagai penghasil protease untuk aplikasi komersial yakni Bacillus, Lactobacillus, Pyrococcus, Termonospora Rhizopus, Mucor, Endothia, dan Aspergillus (Ward, 2009; Sumardi et al., 2016).

Usaha pemberian proteolitik Bacillus sp. yang terbaik berasal dari lingkungan alaminya seperti hutan mangrove. Dari studi literatur hingga saat ini belum banyak isolat Bacillus sp. dari kawasan mangrove digunakan sebagai probiotik. Dalam penelitian ini digunakan bakteri isolat Bacillus sp. UJ132 yang merupakan isolat penghasil protease tertinggi dan belum dikarakterisasi. Isolat tersebut berasal dari hutan mangrove di Desa Margasari, Lampung Timur. Dengan demikian maka perlu dilakukan penelitian untuk mengetahui karakteristik enzim protease yang dihasilkan dari isolat Bacillus sp tersebut.

\section{BAHAN DAN METODE}

\section{Isolat Bakteri}

Isolat bakteri tersebut merupakan koleksi dari Laboratorium Mikrobiologi FMIPA Universitas Lampung. Isolat yang digunakan adalah Bacillus sp. dengan kode isolat UJI32 yang diisolasi dari usus udang pasir di kawasan hutan mangrove. Isolat UJI32 terlebih dahulu diuji kemampuannya menghasilkan protease secara kualitatif . Dalam uji tersebut bakteri diinokulasi ke media skim milk + sea water complete (SWC)-agar yang terdiri atas, $5 \mathrm{~g}$ bacto pepton; $0,1 \mathrm{~g}$ yeast extract; $0,3 \mathrm{~mL}$ gliserol; $75 \mathrm{~mL}$ air laut; $25 \mathrm{~mL}$ aquadest; $1,5 \mathrm{~g}$ agar; dan $1 \mathrm{~g}$ skim milk. Zona jernih yang terbentuk menunjukkan bahwa bakteri tersebut menghasilkan protease.

\section{Pembuatan Starter Bacillus}

Pembuatan media produksi protease dilakukan dengan cara membuat media starter terlebih dahulu. Media starter dibuat sebagai media SWC (sea water complete) ditambahkan 1-3 ose isolat Bacillus sp. Selajutnya diinkubasi dalam shaker inkubator selama 24 jam dengan kecepatan 120 rpm pada suhu ruang.

\section{Optimasi Waktu Produksi Enzim Protease}

Sebanyak $5 \mathrm{~mL}$ media starter $\left(10^{7} \mathrm{sel} / \mathrm{mL}\right)$ ditambahkan ke dalam $45 \mathrm{~mL}$ media produksi SWC. Kultur bakteri diinkubasi ke dalam shaker inkubator masing-masing selama 6, 12, 18, 24, 30, 36 jam dengan kecepatan $120 \mathrm{rpm}$ pada suhu ruang. Sampel disentrifugasi dengan kecepatan 10.000 rpm selama 15 menit pada suhu $4^{\circ} \mathrm{C}$ untuk mendapatkan supernatan. Supernatan tersebut digunakan untuk uji aktivitas, serta karakterisasi enzim protease.

\section{Uji Aktivitas Enzim Protease}

Aktivitas protease diukur dengan metode (Bergmeyer \& Grassl, 1983) menggunakan kasein hammersten sebagai substrat ( $2 \%$ casein dalam 0,01 $\mathrm{M}$ larutan buffer fosfat $\mathrm{pH} 7,0$ ). Sebanyak $0,5 \mathrm{~mL}$ supernatan yang mengandung larutan enzim protease ditambahkan pada 0,1 mL larutan 0,01 M buffer fosfat pH 7. Campuran reaksi diinkubasikan kembali pada suhu $37^{\circ} \mathrm{C}$ selama 10 menit. Reaksi dihentikan dengan menambahkan 0,5 mL 0,1 M trichloroacetic acid (TCA). Selanjutnya supernatan dipisahkan dari endapan dengan sentrifuse pada suhu $4^{\circ} \mathrm{C}$ dengan kecepatan $10.000 \mathrm{rpm}$ selama 10 menit. Sebanyak 0,38 mL filtrat ditambah dengan $1,25 \mathrm{~mL} \mathrm{0,4} \mathrm{M}$ natrium karbonat kemudian ditambahkan $0,25 \mathrm{~mL}$ reagen folin ciocalteau dan diinkubasikan kembali selama 20 menit. Pembacaan optical density (OD) dilakukan pada panjang gelombang $578 \mathrm{~nm}$. Penentuan nilai blanko dilakukan dengan cara yang sama, di mana $0,5 \mathrm{~mL}$ sampel protease diganti dengan $0,5 \mathrm{~mL}$ aquadest. Penentuan nilai standar juga dilakukan dengan cara sama di mana $0,5 \mathrm{~mL}$ sampel protease diganti dengan $0,5 \mathrm{~mL}$ tirosin $5 \mathrm{mM}$. Satu unit (U) aktivitas enzim protease adalah banyaknya enzim yang diperlukan untuk menghasilkan $1 \mu \mathrm{mol}$ tirosin per menit pada kondisi pengujian. Perhitungan aktivitas dilakukan dengan rumus adalah sebagai berikut:

$$
P U=\frac{A_{s p}-A_{b l}}{A_{s t}-A_{b l}} \times \frac{1}{T}
$$

di mana:

PU: unit aktivitas protease (unit/mL)

$A_{s p}$ : nilai absorbansi sampel

$A_{s t}^{s p}$ : nilai absorbansi strandar

$A_{b 1}$ : nilai absorbansi blanko

$T^{b 1}$ : waktu

\section{Karakterisasi Protease}

Karakterisasi protease meliputi uji aktivitas suhu optimum $20^{\circ} \mathrm{C}-70^{\circ} \mathrm{C}$. Pengaruh $\mathrm{pH}$ diuji dengan kisaran $\mathrm{pH}$ 4-12. Satu seri buffer $\mathrm{pH} \mathrm{0,05} \mathrm{M}$ yang berbeda, yakni: pH 4,5 (buffer sitrat); pH 6,7 (buffer fosfat); $\mathrm{pH}$ 8,9 (buffer tris- $\mathrm{HCl}$ ); $\mathrm{pH} 10,11,12$ (buffer glisin- $\mathrm{NaOH}$ ). Uji pengaruh ion logam logam $\mathrm{Ca}_{2}+, \mathrm{Mn}_{2}+, \mathrm{Cu}_{2}+$, $\mathrm{Mg}_{2}+, \mathrm{Fe}_{3}+$, dan senyawa inhibitor asam etilen diamintetraasetat (EDTA) dengan konsentrasi $1 \mathrm{mM}$ dan $5 \mathrm{mM}$. Pegukuran Km dan Vmaks dilakukan dengan menguji konsetrasi substrat $0 \% 1 \% 1,5 \% 2 \% 2,5 \%$ dan 3\% Pada setiap karakterisasi, dilakukan uji aktivitas protease diukur dengan metode Bergmeyer \& Grassl (1983). 


\section{HASIL DAN BAHASAN}

\section{Uji Kualitatif}

Pada uji kualitatif ini terlihat bahwa isolat UJ132 menghasilkan zona bening di sekitar koloni bakteri. Hal ini menunjukkan bahwa isolat UJI32 merupakan bakteri proteolitik atau mampu menghasilkan enzim protease (Gambar 1).

Bacillus sp. UJI 132 juga menghasilkan lainnya yakni selulase dan xilanase (Sumardi et al., 2019). Mikroba tersebut dapat hidup pada media pakan udang dan pakan ikan. Pada media tersebut dapat menghasilkan enzim protase, selulase, dan xilanase.

\section{Optimasi Waktu Produksi}

Penentuan produksi enzim dapat dilakukan dengan cara mengukur aktivitas enzimnya. Konsentrasi enzim tersebut bekerjanya akan berbanding lurus dengan aktivitas enzim. Hasil percobaan membuktikan bahwa pada jam ke- 6 masih rendah $(0,02 \mathrm{U} / \mathrm{mL})$; kemudian pada jam ke-12 naik menjadi 0,04 U/mL. Produksi protease dari isolat Bacillus sp. UJI32 optimum adalah pada jam ke-18 sebesar 0,09 U/mL (Gambar 2).

Pada waktu jam ke-24 sampai dengan jam ke-36 produksi enzim menurun karena berkurangnya jumlah substrat yang dipecah. Produk enzim yang terbentuk dan produk lainnya berupa asam dapat menghambat pembentukan kompleks enzim substrat. Akibat gangguan tersebut bisa terjadi perubahan struktur, sehingga sisi aktif enzim mengalami perubahan dan tidak dapat digunakan dalam mengikat substrat secara baik (Yunita, 2012). Dugaan lain yakni kebutuhan nutrisi asam amino oleh bakteri sudah terpenuhi, atau bakteri mulai mengalami lisis atau mati (Yuniati et al., 2015). Aktivitas protease dari isolat Bacillus sp. UJ132 sebesar $0,09 \mathrm{U} / \mathrm{mL}$. Hasil ini lebih besar jika dibandingkan dengan penelitian Inten et al. (2015) yang melaporkan ekstrak tanah mangrove memiliki aktivitas protease mencapai $1,9 \times 10^{-4} \mathrm{U} / \mathrm{mL}$. Berdasarkan penelitian Yuniati et al. (2015), aktivitas proteolitik dari isolat Bacillus sp. B1 yang diisolasi dari rizosfer tanaman sawi menunjukkan aktivitas optimumnya pada waktu produksi 30 jam. Aktivitas enzim Bacillus sp. UJI32 dari penelitian ini masih lebih kecil dibandingkan nilai aktivitas enzim protease Bacillus sp. Vel yang memiliki aktivitas protease tertinggi sebesar $397 \mathrm{U} / \mathrm{mL}$ pada media gelatin cair (Patel et al., 2004). Selain hal tersebut, Nilegaonkar et al. (2006) memberikan laporan yakni enzim protease Bacillus cereus MCM B326 yang diisolasi dari kulit kerbau mempunyai aktivitas maksimum sebesar 126,87 U/mL di medium pati kedelai.

\section{Pengaruh Suhu}

Setiap enzim dapat memiliki aktivitas optimum yang tertentu. Enzim protease dari isolat Bacillus sp. UJ132 memiliki optimum pada suhu $50^{\circ} \mathrm{C}$ (Gambar 3).

Suatu enzim akan memiliki aktivitas yang semakin tinggi jika suhu semakin dinaikkan hingga mencapai aktivitas maksimum. Namun, Jika kenaikan suhu semakin dilakukan ketika enzim mencapai fase maksimum hal ini akan menyebabkan protein dalam

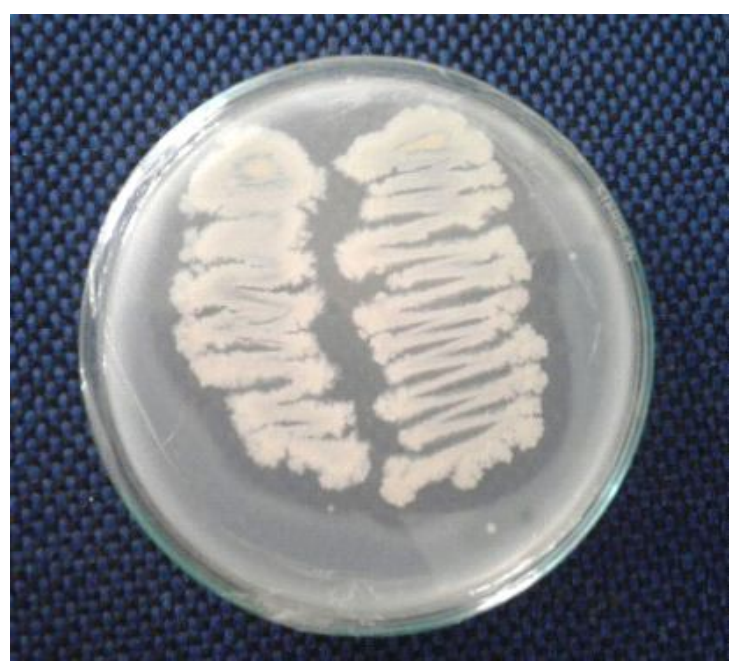

Gambar 1. Bakteri Bacillus sp. UJI132 ditumbuhkan pada media skim milk + SWC-agar umur 24 jam pada suhu ruang.

Figure 1. Bacteria of Bacillus sp. UJI132 was grown on media of skim milk + SWC-agar at room temperature for 24 hours. 


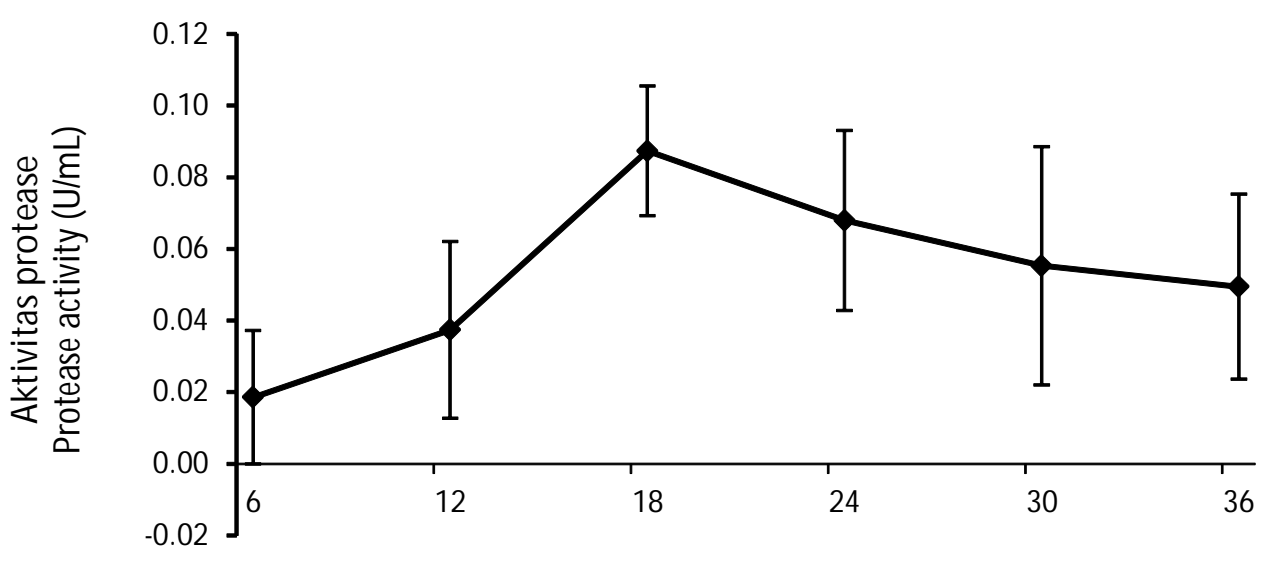

Waktu produksi (jam) / Production time (hours)

Gambar 2. Pengaruh waktu produksi terhadap aktivitas protease.

Figure 2. The effect of production period on protease activity.

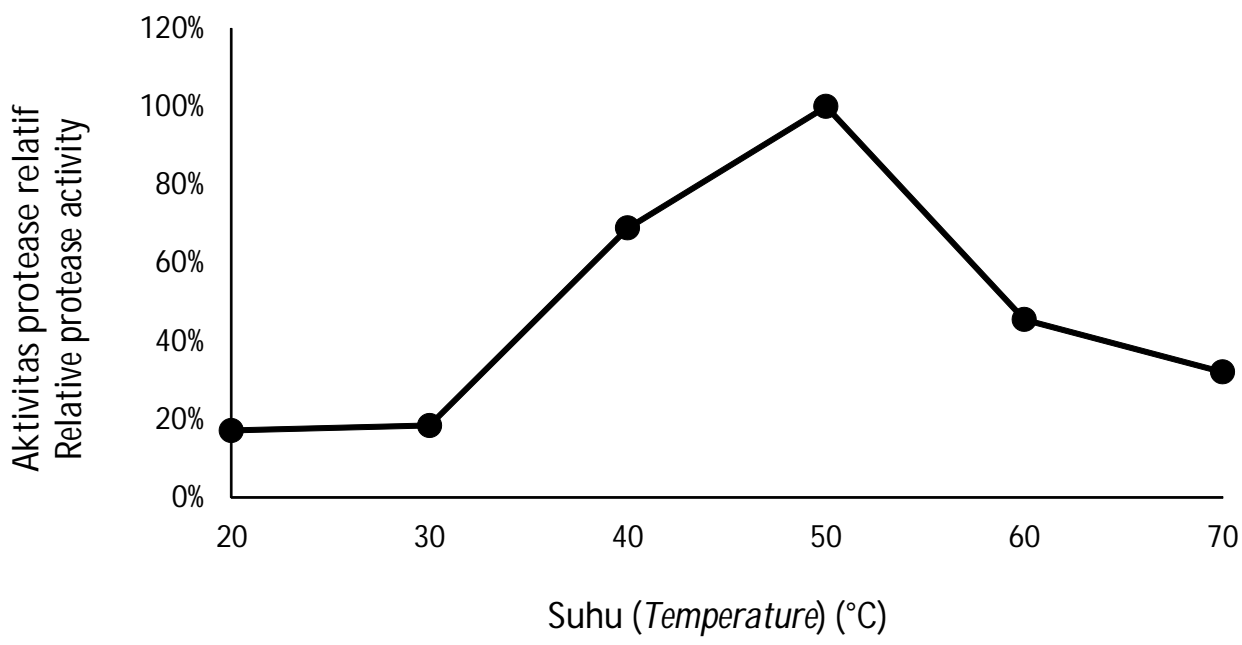

Gambar 3. Pengaruh suhu terhadap aktivitas relatif protease dari Bacillus sp. UJ132.

Figure 3. The effect of temperature on relative protease activity of Bacillus sp. UJ132.

enzim akan terdenaturasi yang menyebabkan penurunan aktivitas enzim hingga kembali ke fase minimum. Pada suhu $20^{\circ} \mathrm{C}$ dan $30^{\circ} \mathrm{C}$ aktivitas protease sebesar $0,01 \mathrm{U} / \mathrm{mL}$ (aktivitas relatif $100 \%$. Nilai tersebut paling rendah dibandingkan aktivitas pada suhu yang lain. Aktivitas tertinggi terjadi pada perlakuan suhu $50^{\circ} \mathrm{C}$ dengan nilai sebesar $0,08 \mathrm{U} / \mathrm{mL}$. Oleh karena itu, suhu $50^{\circ} \mathrm{C}$ merupakan suhu maksimum produksi protease dari isolat Bacillus $\mathrm{sp}$. hutan mangrove. Meskipun aktivitas protease pada suhu $60^{\circ} \mathrm{C}$ tetap ada namun sangat rendah. Hal ini diakibatkan enzim protease telah mencapai fase optimum. Soeka et al. (2011) melaporkan Bacillus licheniformis mempunyai aktivitas optimum pada suhu $60^{\circ} \mathrm{C}$. Yandri et al. (2007) juga melaporkan aktivitas protease hasil pemurnian B. subtilis ITBCCB148 optimum pada suhu $60^{\circ} \mathrm{C}$ enzim protease hasil pemurnian dengan aktivitas $0,91 \mathrm{U} / \mathrm{mL}$.

\section{Pengaruh pH}

pH mempunyai peranan penting terhadap aktivitas suatu enzim. Kondisi lingkungan enzim harus sesuai dengan karakter enzim sehingga enzim dapat bekerja secara optimum dan mencapai hasil yang maksimum. Isolat Bacillus sp. UJ132 hasil isolasi dari sampel udang pasir di hutan mangrove Lampung Timur yang telah diukur aktivitasnya dalam rentang $\mathrm{pH}$ 4-12 mempunyai aktivitas tertinggi pada pH 5 (Gambar 4).

Selain suhu, pH juga memengaruhi aktivitas enzim. Aktivitas protease pada pH 5 terlihat dari Gambar 4 yang memiliki nilai aktivitas enzim protease sebesar 


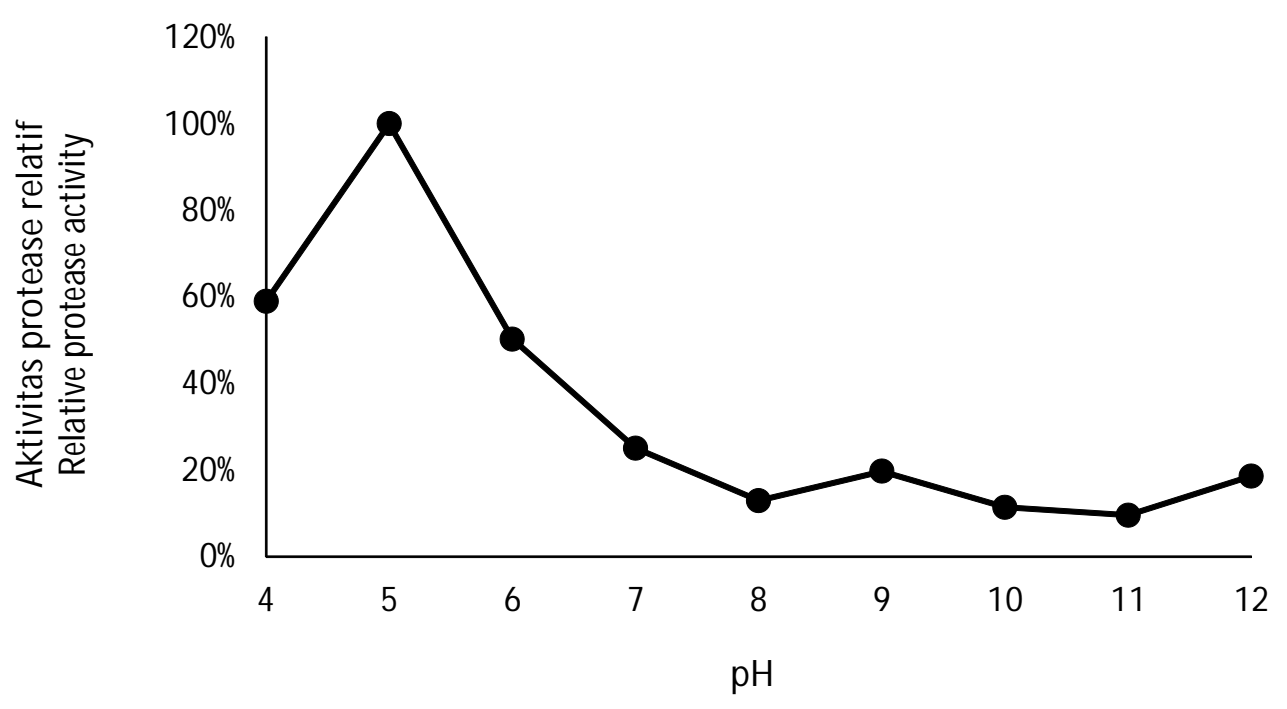

Gambar 4. Pengaruh pH buffer terhadap aktivitas relatif protease dari Bacillus sp. UJ132.

Figure 4. The enfluence of buffer pH on relative protease activity of Bacillus sp. UJ132.

0,09 U/mL. Selanjutnya pada $\mathrm{pH}$ 6-12 aktivtas protease menurun di rentang nilai 0,01 dan $0,02 \mathrm{U} / \mathrm{mL}$. Penurunan aktivitas protease dapat disebabkan karena $\mathrm{pH}$ yang sudah tidak optimum di rentang $\mathrm{pH}$ 6-12. Sehingga dapat dikatakan bahwa kondisi pH maksimum protease isolat Bacillus dari hutan mangrove ada pada pH 5. Pada penelitian Novita et al. (2006) melaporkan bahwa isolat Bacillus amyloliquefaciens NRRL B-14396 memiliki aktivitas optimum pada pH 7,5. Begitu pula Bacillus subtillis yang diisolasi dari terasi Samarinda mempunyai pH optimum 8,5 (Yati \& Sulistiyani, 2014). Perubahan $\mathrm{pH}$ yang ekstrem, enzim dapat mengalami denaturasi akibat gangguan terhadap berbagai interaksi nonkovalen yang menjaga kestabilan struktur tiga dimensi enzim (Hames \& Hooper, 2000).

\section{Pengaruh Ion Logam terhadap Aktivitas Enzim Protease}

Pengaruh ion logam $\mathrm{Ca}^{2+}, \mathrm{Mn}^{2+}, \mathrm{Cu}^{2+}, \mathrm{Mg}^{2+}, \mathrm{Fe}^{2+}$, serta inhibitor spesifik EDTA terhadap aktivitas isolat Bacillus sp. hutan mangrove terlihat pada Gambar 5. Semua ion logam yang ditambahkan pada uji aktivitas protease berfungsi sebagai inhibitor kecuali ion logam $\mathrm{Fe}^{2+}(5 \mathrm{mM})$ yang berfungsi sebagai aktivator (Gambar 5).

Selain suhu dan $\mathrm{pH}$, ion logam juga memengaruhi aktivitas enzim. Ion logam merupakan kofaktor. Kofaktor digunakan untuk mendukung aktivitas katalitik enzim. Ion logam dapat menjadi aktivator dan juga inhibitor. Ion dapat dikatakan aktivator jika dapat menaikkan aktivitas enzim. Sementara, dapat menjadi inhibitor apabila ion logam tersebut menghambat aktivitas protease yang ditandai dengan menurunnya aktivtas enzim. Pada isolat Bacillus $\mathrm{sp}$. UJ132 semua ion logam $\left(\mathrm{Ca}^{2+}, \mathrm{Mn}^{2+}, \mathrm{Cu}^{2+}, \mathrm{Mg}^{2+}\right.$ ) bekerja sebagai inhibitor kecuali ion $\mathrm{Fe}^{2+}$ yang bertindak sebagai aktivator baik pada konsentrasi 1 $\mathrm{mM}$ dan $5 \mathrm{mM}$. Hal ini dapat dilihat dari grafik (Gambar 5). Pada percobaan Sumardi et al. (2018) juga membuktikan bahwa ion logam $\mathrm{Fe}^{2+}$ yang diberi paparan medan magnet 0,2 $\mathrm{mT}$ dalam medium dapat meningkatkan produksi protease pada Bacillus sp. EDTA mempuyai pengaruh yang signifikan dalam aktivitas protease isolat Bacillus sp. UJI132 yakni sebagai inhibitor pada semua reaksi. Perbandingan ion logam sebagai inhibitor atau aktivator dapat dilihat dengan membandingkan setiap aktivitas ion logam dengan kontrol (tanpa ion logam). Hasil penelitian Utarti et al. (2009) menunjukkan bahwa ion logam yang berfungsi sebagai kofaktor protease dari Bacillus sp. 31 adalah ion $\mathrm{Fe}^{2+}$. Hal ini berbeda dengan hasil karakterisasi dari Adinarayana et al. (2003) bahwa serin alkalin protease dari B. subtilis PE-11 kofaktornya adalah ion $\mathrm{Ca}^{2+}, \mathrm{Mg}^{2+}$, dan $\mathrm{Mn}^{2+}$. Sementara pada protease dari Bacillus sp. APR-4 kofaktornya adalah ion $\mathrm{Ca}^{2+}$ dan ion $\mathrm{Cu}^{2+}$ (Kumar \& Bhalla, 2004). Adanya penghambatan ion logam terhadap aktivitas proteaase pada konsentrasi tertentu berkaitan dengan kekuatan ion, dan kekuatan ion itu sendiri memengaruhi konformasi atau struktur tiga dimensi dari protein enzim atau protein substrat (Suhartono, 1989).

\section{Kinetika Enzim (Km dan Vmaks)}

Dari persamaan lineweaver-Burk diperoleh harga Vmaks enzim protease $0,330 \mathrm{U} / \mathrm{mL}$; sedangkan $\mathrm{Km}$ senilai 4,598 $\mathrm{mg} / \mathrm{mL}$ substrat (Gambar 6). 


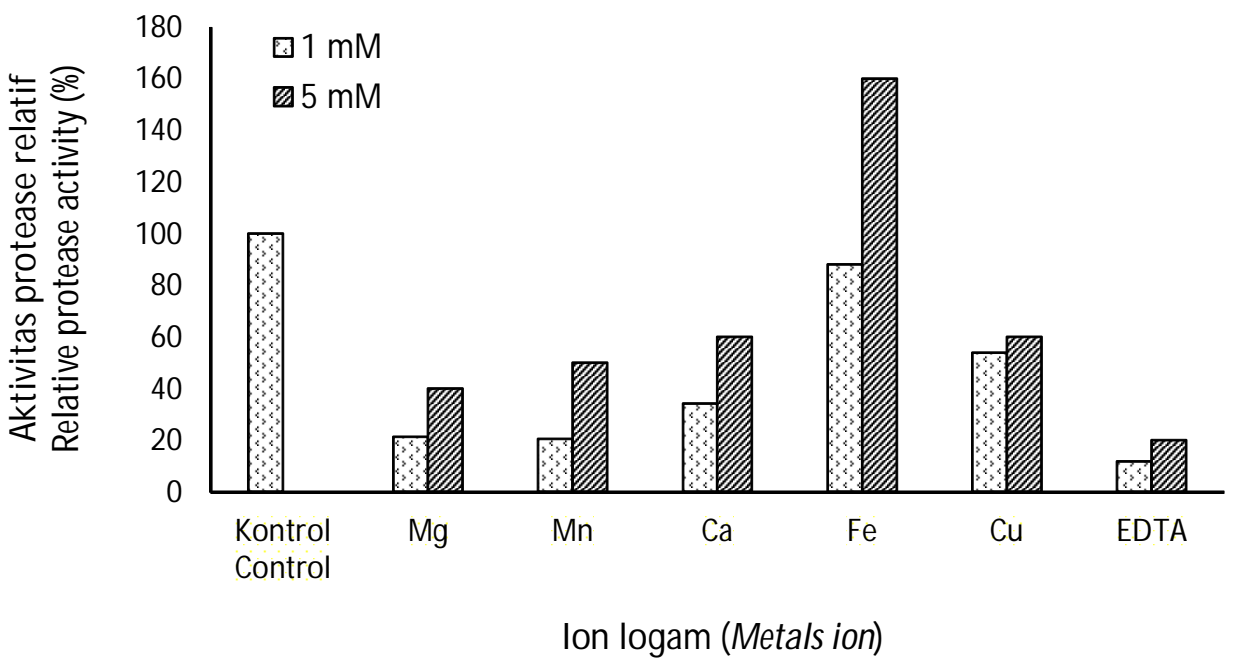

Gambar 5. Pengaruh ion logam dan inhibitor EDTA terhadap aktivitas protease relatif dari Bacillus sp. UJ132.

Figure 5. The effect of metal ion and EDTA inhibitors on relative protease activity of Bacillus sp. UJ132.

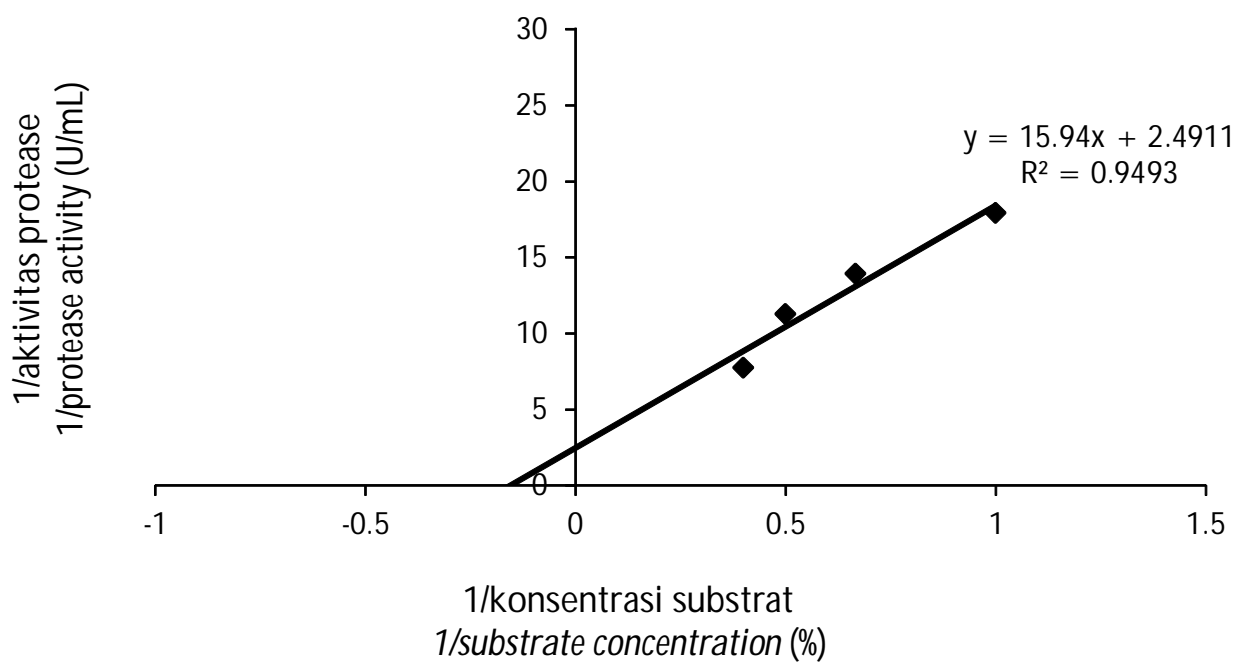

Gambar 6. Kurva lineweaver-Burk ( $1 N$ terhadap $1 /[\mathrm{S}])$ untuk mengetahui kinetika protease dari Bacillus sp. UJ132.

Figure 6. Lineweaver-Burk plot (1/V versus 1/[S]) for determination of kinetic protease of Bacillus sp. UJ132.

Kinetika enzim merupakan saah satu karakteristik yang dibutuhkan dalam mengkarakter suatu enzim. Kinetika enzim sendiri diartikan sebagai setiap konsentrasi substrat yang memengaruhi aktivitas suatu enzim. Dari persamaan Lineweaver-Burk diperoleh harga Vmaks enzim protease $0,330 \mathrm{U} / \mathrm{mL}$; sedangkan $\mathrm{Km}$ senilai 4,598 mg/mL substrat (Gambar 6). Harga Km lebih besar jika dibandingkan dengan isolat Bacillus sp. 31 yang mempunyai nilai Km sebesar $1,5 \times 10^{-3}$ (Utarti et al., 2009). Bila dibandingkan dengan serin protease dari Bacillus sp. 31 yang mempunyai Vmaks 21,32 U/mg (Utarti et al., 2009) kecepatan maksimum protease dari Bacillus sp. 31 tergolong rendah.

\section{KESIMPULAN}

Enzim protease Bacillus sp. UJ132 diproduksi dalam waktu yang relatif singkat (18 jam) dengan nilai kecepatan aktivitas $\mathrm{V}$ maks enzim protease sebesar $0,33 \mathrm{U} / \mathrm{mL}$; walaupun mempunyai daya ikat rendah 
terhadap substrat $(\mathrm{Km} \mathrm{4,59} \mathrm{mg).} \mathrm{Enzim} \mathrm{protease} \mathrm{dari}$ Bacillus sp. UJ132 ini mempunyai kondisi optimum pada pH 5 dan suhu $50^{\circ} \mathrm{C}$.

\section{UCAPAN TERIMA KASIH}

Penelitian ini didanai oleh Hibah Pascasarjana Universitas Lampung dengan kontrak No: 1572/UN26.21 / PP / 2018, tanggal 9 Juli 2018.

\section{DAFTAR ACUAN}

Adinarayana, K., Ellaiah, P., \& Prasad, D.S. (2003). Purification and partial characterization of thermostable serine alkaline protease from a newly isolated Bacillus subtilis PE 11. AAPS Pharm.Sci.Tech, $4(4), 1-9$.

Bergmeyer, H.U. \& Grassl, F. (1983). Method of enzymatic analysis. Third Edition. $\mathrm{VCH}$ (Verlagsgesellschaft), Meinheim, Germany. Volume II (Samples, reagents, assesment of results), p. 1159.

Hames, B.D. \& Hooper, N.M. (2000). Biochemistry: The Instant Notes. Ed.ke-2. Hongkong: Springer-Verlag

Hany, H. (2011). Optimalisasi substitusi tepung Azolla terfermentasi pada pakan ikan untuk meningkatkan produktivitas ikan nila GIFT. Jurnal Teknik Industri, 12(2), 177-181.

Inten, H.N., Nengah, I.W., \& Mayun, L.A.A.I.A. (2015). Analisis potensi protease ekstraseluler tanah hutan mangrove Pantai Suwung Kauh Bali. Cakra Kimia, 3(2), 84-90.

Kumar, D. \& Bhalla, T.C. (2004). Purification and characterization of a small size protease from Bacillus sp. APR-4. Exp. Biol., 42, 515-517.

Moriarty, D.J.W. (1998). Control of luminous Vibrio species in penaeid aquaculture ponds. Aquaculture, 184, 351-358.

Muliani, Nurbaya, Tompo, A., \& Atmomarsono, M. (2004). Eksplorasi bakteri filosfer dari tanaman mangrove sebagai bakteri probiotik pada budidaya udang windu Penaeus monodon. J. Pen. Perik. Indonesia, 2, 47-57.

Murdianto. (2015). Study on the effects of probiotic, Pediococcus acidilactici in the diet on some biological indices of Oscar astronautsocellatus. International Research Journal of Applied and Basic Sciences, 4(11), 3458-3464.

Nilegaonkar, S.S., Zambare, V.P., Kanekar, P.P., Dhakephalkar, P.K., \& Saranik, S.S. (2006). Production and partial characterization of dehairing protease from Bacillus cereus M CM B-326. Bioresource Technology, 98, 1238-1245.

Novita, W., Arief, K., Nisa, F.C., \& Murdiyatmo, U. (2006). Karakterisasi parsial ekstrak kasar enzim protease dari Bacillus amyloliquefaciens NRRL B14396. Jurnal Teknologi Pertanian, 7(2), 96-105.

Patel, R., Dodia, M., \& Singh, S.P. (2004). Extracellular alkaline protease from a newly isolated haloalkaliphilic Bacillus sp.: Production and optimization. Process Biochemistry, 40, 3569-3575.

Soeka, Y.S., Rahayu, S.H., Setianingrum, N., \& Naiola, E. (2011). Kemampuan Bacillus licheniformis dalam memproduksi enzim protease yang bersifat alkalin dan termofilik. Media Litbang Kesehatan, 21(2), 89-95.

Suhartono, M.T. (1989). Enzim dan bioteknologi. Departemen Pendidikan dan Kebudayaan, Direktorat Jenderal Pendidikan Tinggi Antar Universitas Bioteknologi. Institut Pertanian Bogor. Bogor.

Sumardi, Sutyarso, Susanto, G.N., Kurtini, T., Hartono, M., \& Widhi, R.R.E.P.N. (2016). Pengaruh probiotik terhadap kolesterol darah pada ayam petelur (layer). Jurnal Kedokteran Hewan, 10(2), 128-131.

Sumardi, Agustrina, R., Irawan, B., \& Selfiana, I. (2018). Pengaruh paparan medan magnet $0,2 \mathrm{mT}$ padaion logam Fe dan $\mathrm{Zn}$ dalam media pertumbuhan terhadap protease Bacillus sp. Jurnal IImu Lingkungan, 16(2), 173-177.

Sumardi, Ekowati, C.N., \& Rismayanti. (2019). The activity assay of protease, cellulase, amylase, xylanase, and mannanase from Bacillus sp. as a candidate of probiotics. World Journal of Pharmaceutical and Life Sciences, 5(3), 88-93.

Ward, O.P, Rao, M.B., \& Kulkarni, A. (2009). Proteases production. Applied Microbiol. Industrial, p. 495511.

Utarti, E., Nurita, L., \& Arimurti, S. (2009). Karakterisasi protease ekstrak kasar Bacillus sp. 31 characterization of crude protease Bacillus sp. 31. Jurnal Imu Dasar, 10(1), 102-108.

Yandri, T.S., Dian, H., \& Sutopo, H. (2007). The chemical modification of protease enzyme isolated from local bacteria isolate, Bacillus subtilis ITBCCB148 with cyanuric chloride polyethylenglycol. Europ. J. Scien. Resea., 23, 177-186.

Yati, S.S. \& Sulistiyani. (2014). Karakterisasi protease Bacillus subtilis A1 Inacc B398 yang diisolasi dari terasi Samarinda. Berita Biologi, 13(2), 203211.

Yuniati, R., Nugroho, T.T., \& Puspita, F. (2015). Uji aktivitas enzim protease dari isolat Bacillus $\mathrm{sp}$. galur lokal Riau. JOMP FM IPA, 1, 116-122.

Yunita, S.P. (2012). Skrining dan uji aktivitas enzim protease bakteri dari limbah rumah pemotongan hewan. Skripsi. Fakultas Sains dan Teknologi Universitas Airlangga, Surabaya. 